\title{
Impact of Action Research in Education: Experiences and Challenges Faced by Teachers
}

\author{
Jennilee T. Abrenica ${ }^{1}, \&$ Honelly Mae S. Cascolan² \\ ${ }^{1}$ Don Ramon E. Costales Memorial National High School, Pangasinan Division II, \\ Department of Education, Philippines \\ ${ }^{2}$ Pangasinan State University School of Advanced Studies, Philippines \\ DOI - http://doi.org/10.37502/IJSMR.2022.5201
}

\begin{abstract}
The overall goal of this study was to assess the efficacy and impact of action research to secondary education in Pangasinan Division II mother high schools. Specifically, it looked into the experiences and challenges faced by the teachers in conducting action research. Later on, the researchers devised a strategy or a plan of action to help the teachers in doing action research and address the problems they have encountered. A combination of quantitative and qualitative methods of research was used and it utilized 50 secondary teachers from the 21 mother high schools in Pangasinan Division II as respondents. These were the findings: (1) Action research, according to the teachers, has a positive impact in the teaching-learning process (2) It was also helpful in teacher's professional development, particularly in teacher's promotion (3) It has also a positive impact in curriculum creation or development. (4) For the teacher-respondents, doing action research is challenging due to financial restrictions, time constraints, and the Division Office's procedure.
\end{abstract}

Keywords: action research, curriculum development, professional development, teaching learning process, impact, challenges, experiences.

\section{Introduction}

Action research encompasses a wide array of evaluative, investigative, and analytical research approaches aimed at identifying issues or weaknesses in organizations, schools, and classrooms, as well as assisting educators in developing practical solutions to solve them swiftly and effectively. Action research may also be used to enhance programs or educational approaches that may not have any issues but that educators wish to learn more about them and enhance them. The general goal is to create a simple, practical, repeatable process of iterative learning, evaluation, and improvement that leads to increasingly better results for schools, teachers, or programs (Great Schools Partnership, 2015)

Another distinctive definition of action research by Sagor (2004) is it is a tool to help teachers and other educators to uncover strategies to improve teaching practices; it is a viable and realistic endeavor for all educators. Teachers are required to develop a study in an area of 
interest that they would like to conduct in their classrooms or schools as part of action research. Because teachers regularly test a new instructional technique, review a new curricular program, or evaluate an existing pedagogical method, action research is usually viewed as a professional development opportunity. In addition, participating in or doing an action research has been proven to be the catalyst for positive change in many research projects, as evidenced by teacher improvement, self-reflection, and general learning that improves classroom practices (Ferrance, 2000; Johnson, et.al., 2000; Ross, et. al., 1999; Sax, et.al., 2001).

In the Philippines, the Department of Education (DepEd) defines action research as "a process of systematic, reflective inquiry to improve educational practices or resolve problems in any operation unit, such as school, classroom or office". (DepEd Order No. 16 s. 2017). It is almost impossible for a teacher to avoid performing action research because it is one of the requirements for them to be promoted from their present teaching position or rank to the next level. In addition, due to the frequent changes in the educational system, one may choose to undertake research in order to meet the demands of learners in a changing environment.

Many reasons, such as ASEAN integration, global competitiveness, globalization, integration of ICT in teaching, and other key internal and external variables, are causing the Philippine educational system to quickly evolve. Teach for the Philippines Organization (2013) stated that: "on May 15, 2013, President Benigno Aquino, III approved Republic Act (RA) 10533, signing into law the $\mathrm{K}+12$ program. The $\mathrm{K}+12$ program covers kindergarten and twelve years of basic education - six years of primary schooling, four years of junior high school and two years of senior high school". K+12 seeks to offer mastery of skills for lifelong learners and prepare students for professional options by adding two years to the present educational system. The program additionally contextualizes teachings for pupils by explaining ideas in terms of local culture and utilizing the students' native languages. Graduates will also be prepared to gain mid-level skills, which will provide them additional chances in the global employment market.

Because of the shift in the Philippine educational system, studies or research must be conducted in order to address potential difficulties and consequences as a result of the transition. Because of the growing difficulties and concerns in many areas of the teaching and learning process, the number of teachers undertaking action research in DepEd has risen over the years. In addition to this, the competition for professional growth and promotion is very tight in DepEd. One of the criteria in the computation of points during ranking, as stipulated in DepEd Order No. 66, s. 2007 or the Revised Guidelines on the Appointment and Promotion of Other Teaching, Related Teaching, and Non-Teaching Positions is to have an outstanding performance. Research and development projects are evaluated in this criterion, with various scoring methods depending on whether the research was done at the school, district, or division level. Teachers undertake or conduct action researches during the school year, and these research development initiatives are related to it.

Teachers across the world, including the Philippines, do action research for these reasons. Teachers and students, as well as policy-making bodies in education, might benefit from action research to enhance the curriculum, practices, pedagogies, and tactics of teachers, impacting student performance, skills, and attitudes. The scope of these advantages was investigated in this study. This research looked at how far and how impactful action research has been in science education, particularly in addressing and solving learners' identified learning problems 
and issues, as well as how teachers and mentors have benefited from action research in terms of teaching strategies, pedagogies, and even professional growth and promotion. The researchers also sought to learn about the experiences, challenges, and problems that the teachers had while conducting their action research and, as a result, what action plan or strategies might be presented to solve those difficulties and problems.

\section{Conceptual Framework}

Ferrance (2000) stated that "action research is a form of research that is authentic and meaningful to the teacher-researcher because it is conducted by the teacher in his/her own classroom space. Action research helps teachers to "pick up threads suggested in academic circles, and weave them in their own classroom". Action research is taking a self-reflective, critical, and methodical approach to analyzing one's teaching environments, with the goal of intervening in the problematic situation in a purposeful way to bring about improvements and even better practice. Furthermore, action research is in the hands of teachers, and the process of teachers analyzing their own teaching methods includes reflexivity, action, and transformation.

It is generally known that learning occurs only when the student has personal objectives. An increasing corpus of worldwide research suggests that teachers should question their own teaching methods. Furthermore, it has been recommended that integrating teacher candidates in the investigation of their own practices is a good method to improve their professional growth since it encourages introspection. Tindowen (2019) presented in their study the difficulties of teachers in the different parts of action research writing.

These findings were connected to the researchers' study, which aimed to establish how successful action research is in science education, especially in the teaching-learning process, teacher professional development, and curriculum creation. This research looked into not just the difficulty of writing action research, but also other potential obstacles that teachers may have faced when writing and doing action research.

Other difficulties and concerns not previously explored by the referenced academics were discovered during this research investigation. These will subsequently assist other teachers, instructors, and researchers, institutions, and the division in developing potential solutions or action plans to address the difficulties and concerns that this research will create. This is intended to lead to improved action research conduct and execution, which would eventually benefit teachers and instructors, who will in turn benefit children who get methods generated from action research.

A process flow is the representation of the conceptual framework of this study. It is patterned form the Input-Process-Output (IPO) Model that guided the researcher in the development of proposed plan of action to boost teachers' interest in conducting action research. The IPO model is shown in Fig. 1 in the succeeding page.

Fig. 1 shows the entire flow of how the research was conducted and led to the development of a proposed plan of action to help the teachers in doing action research and address the encountered problems and challenges. The first box shows the inputs which consist of the degree of efficacy and impact of the conducted action research by the teacher and difficulties or problems encountered by the teachers in conducting action research. 
The second box shows the process that was involved in the conduct of the study which included the analyses of the data that were gathered: degree of efficacy and impact of the conducted action research by the teacher and the problems encountered by the teachers in conducting action research. After the analyses on the data gathered and upon identifying the problems encountered, the plan of action to help the teachers in doing action research and address the encountered challenge. This was the output of this study.

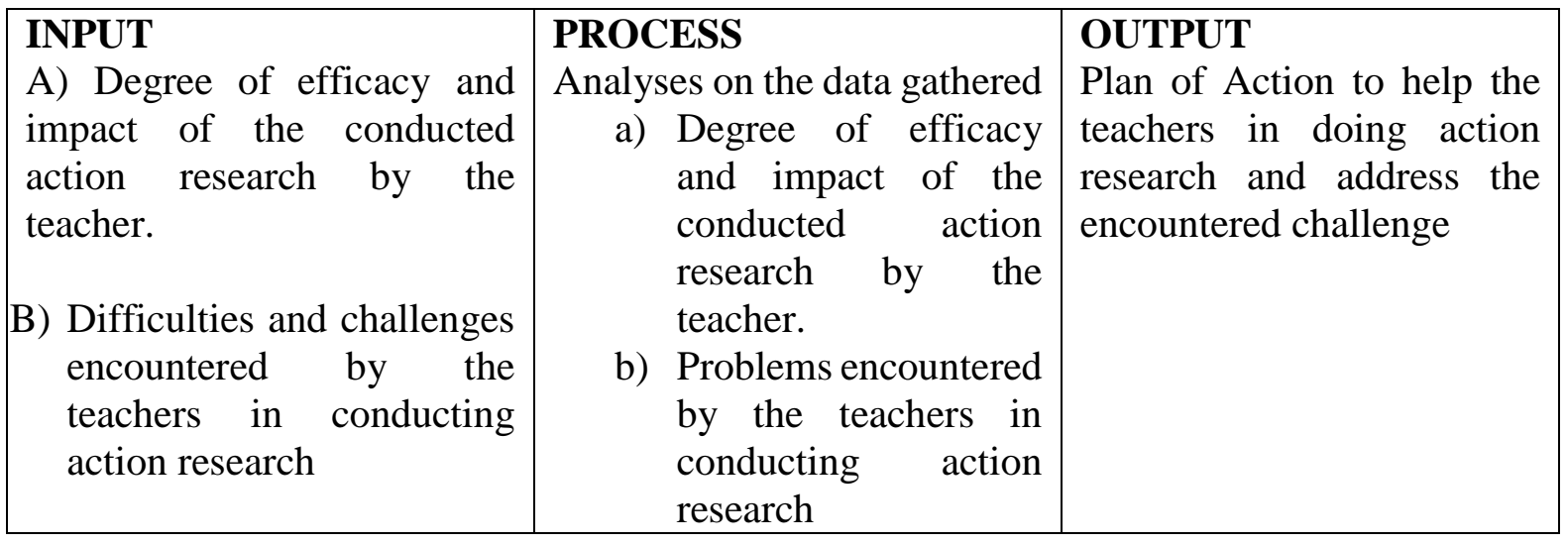

Figure 1. Research paradigm of the study.

\section{Objectives of the study}

The overall goal of this study was to assess the efficacy and impact of action research to education in Pangasinan Division II mother high schools. Specifically, it looked into the experiences, difficulties, and challenges faced by the teacher-respondents in conducting action research. Later on, the researchers devised a strategy or a plan of action to help the teachers in doing action research and address the problems they have encountered.

\section{Materials and Methods}

A combination of quantitative and qualitative methods of research was used and it utilized 50 teachers from the 21 mother high schools in Pangasinan Division II as respondents. According to Creswell (2003), "quantitative research employs strategies of inquiry such as experimental and surveys, and collect data on predetermined instruments that yield statistical data". Qualitative research, on the other hand, is the process of collecting, analyzing, and interpreting non-numerical data, such as language. Qualitative research can be used to understand how an individual subjectively perceives and gives meaning to their social reality (McLeod, 2019).

\subsection{Respondents of the Study}

In this study, teachers from 21 mother high schools of Pangasinan Division II, who had performed action research, were invited to participate in the survey. A total of 50 teachers answered the survey questionnaires via Google form. The list of teachers was obtained from the Schools Division Research Committee (SDRC) of the Planning Department of the Curriculum and Implementation Division. 


\subsection{The Instrument}

The tool used in this study was a survey questionnaire created by the researchers to collect data for the level of efficacy and impact of action research to science education. The survey instrument was adapted from O'Connor, Greene, and Anderson's research as well as Tindowen, Guzman, and Macanang's.

For the qualitative part, open ended questions were used to elicit from the teachers their experiences, challenges and problems they have encountered in the conduct of their action research.

\subsection{Data Analyses}

For the efficacy and impact of action research, the researchers employed a Likert scale type of questionnaire. "A question on a five-point or seven-point scale is known as a Likert scale. The degrees of efficacy of action research range from Very Highly Effective to Slightly Effective. With this, the survey creator may receive a comprehensive picture of the teachers' viewpoints. Rensis Likert, a social psychologist, created the Likert scale in 1932" (Jamieson, 200).

For the degree of efficacy and impact, mean was used to interpret the data gathered. Refer to Table 1 for the interpretations range:

Table 1. Interpretation of teachers' rating range on efficacy and impact of action research and level of difficulty of the encountered problems.

\begin{tabular}{lll}
\hline Mean Range & $\begin{array}{l}\text { Interpretation on efficacy and } \\
\text { impact of action research }\end{array}$ & $\begin{array}{l}\text { Interpretation on level of } \\
\text { difficulty of the encountered } \\
\text { problems. }\end{array}$ \\
\hline 4.21 to 5.00 & Very Highly Effective & Very Extremely Difficult \\
3.41 to 4.20 & Highly Effective & Extremely Difficult \\
2.61 to 3.40 & Effective & Difficult \\
1.81 to 2.60 & Moderately Effective & Moderately Difficult \\
1.00 to 1.80 & Slightly Effective & Slightly Difficult \\
\hline
\end{tabular}

Thematic analysis was utilized to investigate the experiences, difficulties and obstacles that the teachers faced when doing action research in the qualitative data.

\section{Results and Discussion}

\subsection{Degree of efficacy and impact of action researches in education}

This study examined the usefulness of action research in the teaching-learning process, teacher's professional development, and curriculum creation using frequency and mean. The values collected from the investigation were evaluated and interpreted using the scale in Table 1.

Table 2 demonstrates that the teacher-respondents feel that action research is extremely beneficial and effective in the teaching-learning process with a mean of 4.18 ; boosting 
motivation among students had the highest mean of 4.24. This indicates that science teachers believe that action research is extremely helpful in raising students' enthusiasm in class. Teachers also believe that action research is extremely highly beneficial or effective, with a mean of 4.36, in teacher's professional development; and the respondents gave the highest rating, a mean of 4.48 , for number 6 , which is very beneficial in teacher' promotion. Finally, teachers feel that action research is very beneficial or effective, with a mean of 4.16 , in terms of curriculum development. It greatly aids in the development of curricular materials that are appropriate for students. This indicator had a mean of 4.18, highly effective.

On the efficacy of action research in education, an overall mean of 4.23 was found, indicating that it is very highly effective or beneficial. Action research, according to the teachers who participated in this study, is extremely effective and helpful in three areas: teaching learning processes, professional development, and curriculum development or creation.

Table 2. Frequencies, percent, mean, and interpretation of teachers' rating on efficacy and impact of action researches.

\begin{tabular}{|c|c|c|c|c|c|c|c|}
\hline \multirow[b]{3}{*}{ Level of Efficacy } & $V H$ & & & & & \multirow[b]{4}{*}{ Mea } & \multirow{4}{*}{$\begin{array}{l}\text { Interpret- } \\
\text { ation }\end{array}$} \\
\hline & $E$ & $H E$ & $E$ & $M E$ & $S E$ & & \\
\hline & (5) & (4) & (3) & $(2)$ & (1) & & \\
\hline & $\mathrm{f}$ & $\mathrm{f}$ & $\mathrm{f}$ & $\mathrm{f}$ & $\mathrm{f}$ & & \\
\hline Indicators & $\%$ & $\%$ & $\%$ & $\%$ & $\%$ & $\mathrm{n}$ & \\
\hline
\end{tabular}

Teaching-Learning Process

4.24 VHE

$\begin{array}{llllll} & 17 & 28 & 5 & 0 & 0 \\ \text { 1. Increasing motivation among students. } & 34 & 56 & 10 & 0 & 0\end{array}$

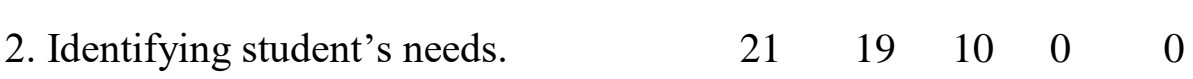

4.22 VHE

$\begin{array}{lllll}42 & 38 & 20 & 0 & 0\end{array}$

$\begin{array}{lllllll}18 & 24 & 8 & 0 & 0 & 4.20 & \text { HE }\end{array}$

3. Contributing greatly to the profession's $\begin{array}{llllll}36 & 48 & 16 & 0 & 0\end{array}$

body of knowledge about teaching and learning.

4.12 HE

$\begin{array}{llllll} & 16 & 25 & 8 & 1 & 0 \\ \text { 4. Improving performance of students. } & 32 & 50 & 16 & 2 & 0\end{array}$

4.12 HE

5. Enhancing communication between $\begin{array}{llllll}17 & 22 & 11 & 0 & 0\end{array}$

$\begin{array}{lllllll}\text { teachers and students. } & 34 & 44 & 22 & 0 & 0\end{array}$

Mean

4.18 HE

Teacher's Professional Development

4.48 VHE

6. Helpful in a great deal in teacher's $\begin{array}{llllll}29 & 16 & 5 & 0 & 0\end{array}$ promotion.

$\begin{array}{lllll}58 & 32 & 10 & 0 & 0\end{array}$


7. Improving teacher's teaching practices $\begin{array}{llllll}26 & 20 & 3 & 1 & 0\end{array}$ and strategies.

$\begin{array}{lllll}52 & 40 & 6 & 2 & 0 \\ 26 & 16 & 8 & 0 & 0\end{array}$

4.36 VHE

8. Helpful in a great deal in teacher's $\begin{array}{llllll}52 & 32 & 16 & 0 & 0\end{array}$ professional development.

4.32 VHE

9. Expanding curriculum perspectives, $\begin{array}{llllll}21 & 24 & 5 & 0 & 0\end{array}$

$\begin{array}{llllll}\text { choices and thinking as a teacher. } & 42 & 48 & 10 & 0 & 0\end{array}$

4.22 VHE

10. Giving more confidence in teacher's $\begin{array}{llllll}22 & 18 & 9 & 1 & 0\end{array}$ $\begin{array}{llllll}\text { work. } & 44 & 36 & 18 & 2 & 0\end{array}$

Mean

$4.36 \quad V H E$

Curriculum Development

$\begin{array}{llllllll}\text { 11. Helps a great deal in coming up with } & 16 & 27 & 7 & 0 & 0 & \mathbf{4 . 1 8} & \mathrm{HE}\end{array}$

curriculum materials applicable to $\begin{array}{llllll}32 & 54 & 14 & 0 & 0\end{array}$

learners.

$\begin{array}{lllllllll}17 & 24 & 9 & 0 & 0 & 4.16 & \mathrm{HE}\end{array}$

12. Sharing and collaboration across $\begin{array}{llllll}34 & 48 & 18 & 0 & 0\end{array}$

departments, disciplines, and grade levels.

4.16 HE

$\begin{array}{llllll}\text { 13. Developing priorities for assessment } & 17 & 24 & 9 & 0 & 0 \\ \text { efforts. } & 34 & 48 & 18 & 0 & 0\end{array}$

4.16 HE

14. Developing priorities for schoolwide $\begin{array}{llllll}15 & 28 & 7 & 0 & 0\end{array}$

$\begin{array}{llllll}\text { planning. } & 30 & 56 & 14 & 0 & 0\end{array}$

$\begin{array}{llllllll}16 & 24 & 10 & 0 & 0 & 4.12 & \mathrm{HE}\end{array}$

15. Increasing dialogue about $\begin{array}{llllll}32 & 48 & 20 & 0 & 0\end{array}$

instructional issues and student learning.

Mean

$4.16 \quad H E$

Overall Mean

$4.23 \quad V H E$

Legend:

Very Highly Effective (VHE) Highly Effective (HE) Effective (E) Moderately Effective

(ME) Slightly Effective
4.21-5.00
$3.41-4.20$
2.61-3.40
$1.81-2.60$

\subsection{0-1.80}

According to Hong and Lawrence's (2011) research, all teacher respondents saw a link between increased student freedom and improved learning outcomes and motivation. Better fluency, continuing activation of past information, increased understanding, "terrific connection with peers," and "more pleasure of reading," according to one teacher's reflection. According to Aguilar-De Borja's (2018) research, instructors believe that action research is beneficial to the teaching and learning process for students. The majority of the instructors' 
remarks focused on the impact of action research on students' academic achievement. Students may maintain track of their performance during the teaching-learning process, according to teachers. Furthermore, action research aids students' academic achievement as judged by their professors. The same conclusions can be seen in this study, which focuses on the teachinglearning process.

The conclusions of this study on the efficacy and impact of action research in teacher development are similar to those of Aguilar-De Borja's study (2018). Action research has a very high degree of efficacy in terms of teacher professional development, according to the study's respondents. Nonetheless, Aguilar-De Borja discovered in her research that 26 of 27 (96 percent) instructors agreed that the action research project had a beneficial influence on their teaching. Action research has aided most of the instructors in improving their tactics, approaches, and teaching styles, according to the majority of them. Some of them commented that, "design better training programs for teachers and students," "I need to revise or modify my teaching styles because the results of research suggest it. Thus, it helps improve the teaching and help me realize to consider other factors in my teaching process," "it gave me an idea of what methods must be continued and which methods must be changed/improved," "very beneficial to the teachers and learners", and "learned different strategies." She also noted in her research that action research has a long-term professional influence. When asked about the long-term career impact of action research projects, most teachers believe that conducting action research will assist them in their professional growth through promotions and ranking because research output can be considered a factor in the merit system/advantage for employment purposes.

Chow (2015) found that teachers' active participation in refining and implementing the research project led to profound changes in the curriculum design of various subjects at their schools in their study entitled "Teachers as Researchers: A Discovery of Their Emerging Role and Impact Through a School-University Collaborative Research." Teacher research has the potential to enhance school-based curriculum design. This is supported by the findings of this study, which found that instructors feel action research is very useful in developing current curricula. Respondents in Aguilar-De Borja's study (2018) indicated that when teachers undertake action research, curriculum design improves because their voices/insights/ideas are heard and accepted by administrators, which they may employ in their instructional practices.

\subsection{Experiences, Difficulties, and Challenges Encountered by Teachers in Conducting Action Research}

This section illustrates the experiences and the difficulties experienced by the teachers during the conduct of their action study using frequency and mean. The values acquired from the investigation were examined and interpreted once again using the scale in Table 1. Each indicator's mean score was calculated and examined. Table 3 displays the frequency, percent, mean, and interpretation of science teachers' ratings of the degree of difficulties of issues encountered during their action research.

Fifteen (15) out of the 50 respondents rated "finances as an extremely difficult part for them. According to Respondents 2,14, 17 and 18, "with a family to feed and daily expenses, the cost of conducting action research was one of our concerns and we consider this as a 
challenge to us". Respondents 1, 12, 23, and 27, despite being single, shared that "conducting action research is somehow costly and can burden us because this is not part of our daily budget." Torreces (2019) mentioned a cost estimate of Php 30,000 for performing an action research in a presentation regarding Action Research Guide. This would include surveying, especially if a teacher is unfamiliar with Google forms, internet connections, duplicating survey materials, and statistical treatment, among other things. According to the guide, conducting action research will result in a reduction in a teacher's budget. It would also cost a teacher money to travel to the division office to review, revise, and submit papers. These discussions by Torreces would support the concerns of the respondents in terms of the finances that will be used in conducting action researches.

For the second most challenging issue, this research revealed that science teachers struggled to undertake action research due to time constraints. Due to their teaching schedules and other employment responsibilities, their ability to undertake action research may be hampered. 12 out of 50 teachers rated this aspect as extremely difficult for them. Respondents 1,5 , and 8 , during the survey, said that "aside from our teaching loads, we all have other designations in school. These designations give us more work and tasks to accomplish which could interfere in the conduct of action research and may affect our concentration". Respondent 18 \& 26 said that "we are Guidance Counselors, Boy Scout/Girl Scout Coordinators, Disaster Risk Reduction Management Coordinators, among other designations that we have."

According to the Dissertation Revision (2017), one of the Top 10 Challenges Faced by Researchers in Developing Countries is time management. It was third on their list. Learning the skills and practical implementation consume ample time. In this case, doing intense and good research and drafting a high caliber research paper becomes difficult or hard to do for teachers. Another conclusion from Aguilar-De Borja's study (2018) was that the majority of instructors cited time constraints as one of the challenges in doing action research. Finding time to undertake research is always a challenge for teachers. Because performing research necessitates time, the majority of them stated that time management has always been a major consideration. When a teacher is overburdened with many preparations, it is difficult to stay on schedule. Furthermore, one instructor stated that finding time to gather information and write is difficult, especially if you are a full-time teacher. It is tough to write during free time since it has already been assigned to aiding pupils; moreover, teachers must concentrate on lessons outside of school hours, making writing time extremely challenging. This conclusion is also consistent with the findings of this survey, since this difficulty ranks second on the list of issues that teachers face.

A total of 12 teachers gave an extremely difficult rating for the process being followed set by the Division Office in conducting research. The mean here was 3.50 which has a descriptive rating of extremely difficult. A sequence of actions should be completed according to DO No. 16 s 2017 or the Research Management Guidelines. It begins with the Request for Research Proposals, followed by the Evaluation of Proposals, Screening of Proposals, Committee Evaluation, Results Notification, Progress Monitoring, Submission and Acceptance, and Dissemination and Utilization. While they are all done at the Division Office 
except for the research itself, it might be a problem for instructors because they are all done in the Division Office

The study had an overall mean of 3.15 for the degree of difficulty in conducting action research, indicating that the teachers considered doing action research difficult.

Table 3. Frequencies, percent, mean, and interpretation of teachers' rating on the degree of difficulty of the problems encountered in the conduct of action research.

$\mathbf{n}=\mathbf{5 0}$

\begin{tabular}{|c|c|c|c|c|c|c|c|}
\hline \multirow[b]{3}{*}{ Level of Difficulty } & $V E$ & & & $M$ & & \multirow{5}{*}{$\begin{array}{l}\text { Mea } \\
\mathrm{n}\end{array}$} & \multirow{5}{*}{$\begin{array}{l}\text { Interpret- } \\
\text { ation }\end{array}$} \\
\hline & $D$ & $E D$ & $D$ & $D$ & $S D$ & & \\
\hline & $(5)$ & $(4)$ & (3) & (2) & (1) & & \\
\hline \multirow[b]{2}{*}{ Indicators } & $\mathrm{f}$ & $\mathrm{f}$ & $\mathrm{f}$ & f & $\mathrm{f}$ & & \\
\hline & $\%$ & $\%$ & $\%$ & $\%$ & $\%$ & & \\
\hline \multirow{4}{*}{$\begin{array}{l}\text { 1. Finances in the conduct of action } \\
\text { research. }\end{array}$} & & & & & & & Extremel \\
\hline & 15 & 13 & 14 & 7 & 1 & 3.68 & $\mathrm{y}$ \\
\hline & 30 & 26 & 28 & 14 & 2 & & Difficult \\
\hline & & & & & & & Extremel \\
\hline \multirow{3}{*}{$\begin{array}{l}\text { 2. Time management because of teaching } \\
\text { loads and other work assignments. }\end{array}$} & 12 & 10 & 20 & 8 & 0 & 3.52 & $\mathrm{y}$ \\
\hline & 24 & 20 & 40 & 16 & 0 & & Difficult \\
\hline & & & & & & & Extremel \\
\hline \multirow{4}{*}{$\begin{array}{l}\text { 3. Process being followed set by the } \\
\text { Division Office in conducting research. } \\
\text { 4. Additional Workload and burden in the } \\
\text { part of the teacher. }\end{array}$} & 12 & 11 & 19 & 6 & 2 & 3.50 & $\mathrm{y}$ \\
\hline & 24 & 22 & 38 & 12 & 4 & & Difficult \\
\hline & 8 & 12 & 20 & 9 & 1 & 3.34 & Difficult \\
\hline & 16 & 24 & 40 & 18 & 2 & & \\
\hline \multirow[t]{2}{*}{ 5. Writing the paper itself. } & 4 & 10 & 25 & 10 & 1 & 3.12 & Difficult \\
\hline & 8 & 20 & 50 & 2 & 2 & & \\
\hline \multirow{5}{*}{$\begin{array}{l}\text { 5a. } \cdot \text { Making a relevant presentation on the } \\
\text { project and write article for publication } \\
5 \text { b. } \cdot \text { Analyzing qualitative data }\end{array}$} & 7 & 11 & 21 & 9 & 2 & 3.24 & Difficult \\
\hline & 14 & 22 & 42 & 18 & 4 & & \\
\hline & & & & & & & Difficult \\
\hline & 7 & 10 & 22 & 10 & 1 & 3.24 & \\
\hline & 14 & 20 & 44 & 20 & 2 & & \\
\hline \multirow[t]{3}{*}{$5 c . \cdot$ Organizing and writing the findings } & & & & & & & Difficult \\
\hline & 4 & 13 & 22 & 10 & 1 & 3.18 & \\
\hline & 8 & 26 & 44 & 20 & 2 & & \\
\hline \multirow[t]{3}{*}{ 5d. $\cdot$ Related or Relevant Literature } & & & & & & & Difficult \\
\hline & 4 & 13 & 21 & 9 & 3 & 3.12 & \\
\hline & 8 & 26 & 42 & 18 & 6 & & \\
\hline \multirow[t]{3}{*}{ 5e. $\cdot$ Analyzing quantitative data } & & & & & & & Difficult \\
\hline & 5 & 9 & 22 & 11 & 3 & 3.04 & \\
\hline & 10 & 18 & 44 & 22 & 6 & & \\
\hline \multirow{2}{*}{$\begin{array}{l}\text { 5f. - Using technology in writing and in } \\
\text { making presentation }\end{array}$} & 4 & 8 & 19 & 12 & 7 & 2.80 & Difficult \\
\hline & 8 & 16 & 38 & 24 & 14 & & \\
\hline
\end{tabular}




\begin{tabular}{|c|c|c|c|c|c|c|c|}
\hline 6. Identifying issues and problems to be & 5 & 14 & 13 & 16 & 2 & 3.08 & Difficult \\
\hline investigated by action research & 10 & 28 & 26 & 32 & 4 & & \\
\hline 7. Knowledge regarding the conduct of & 6 & 7 & 20 & 12 & 5 & 2.94 & Difficult \\
\hline action research. & 12 & 14 & 40 & 24 & 10 & & \\
\hline $\begin{array}{l}\text { 8. Motivation and support from } \\
\text { supervisors. }\end{array}$ & & & & & & & Difficult \\
\hline & 4 & 8 & 20 & 14 & 4 & 2.88 & \\
\hline & 8 & 16 & 40 & 28 & 8 & & \\
\hline 9. Motivation and support from peers. & & & & & & & Difficult \\
\hline & 5 & 7 & 19 & 14 & 5 & 2.86 & \\
\hline & 10 & 14 & 38 & 28 & 10 & & \\
\hline 10. Participation of students in the conduct & 5 & 9 & 17 & 12 & 7 & 2.86 & Difficult \\
\hline of action research. & 10 & 18 & 34 & 24 & 14 & & \\
\hline Overall Mean & & & & & & 3.15 & Difficult \\
\hline
\end{tabular}

Legend:

Very Extremely Difficult (VED) Extremely Difficult (ED) Difficult (D) Moderately Difficult (MD) Slightly Difficult (SD)
4.21-5.00
$3.41-4.20$
$2.61-3.40$
$1.81-2.60$

$1.00-1.80$

All of the other criteria were rated as difficult by the teachers, with the least difficult being using technology in writing and presenting presentations, which received a mean score of 2.80 .

According to Tindowen (2019), instructors have challenges in doing action research, particularly in terms of literature search, presentation and publication of findings, and data collecting. Finally, increased effort and stress on the part of the teacher, writing anxiety, lack of time, and inadequate expertise in the conduct of action research identified as the key difficulties and obstacles of instructors in the conduct of action research. These were also true in this study, as science teachers found doing action research difficult. The findings of this study suggest that science teachers find doing action research challenging for a variety of reasons discussed before. These should be the attention of those in charge of administration and the SDRC in order to solve these challenges and assist teachers in undertaking action research.

\subsection{Plan of Action to help the teachers in doing action research and address the encountered challenges}

With so many benefits and advantages for students, instructors, administrators, and even the curriculum, action research should be actively conducted, communicated, and used. Following multiple conversations, readings, and research, a plan of action was developed to encourage teachers to engage in action research because of the numerous benefits it may provide.

The main objective of this Plan of Action is to help the teachers in doing action research and address the encountered challenges. Teachers should be updated on a regular basis since 
life is a continual learning process. Orientation, seminars, and trainings for teachers are crucial since they will educate them how to undertake or conduct action research.

For the problems in finances, there are research grants available that can be offered to those interested in research. An example of this is the Basic Education Research Fund (BERF). It is a grant provided by the Department of Education to support education research in aid of evidence-based policy formulation (DO No. $16 \mathrm{~s}$ 2017). Teachers can maximize this benefit by applying in this grant. This will not only help them financially but help them go through all process of doing their action research or study.

With regards to teaching schedules and time constraints, teachers should follow or should make a timetable that they can follow during the course of their research. They should have a clear schedule on what they should do and prioritize. They can make use of Gantt charts to go with their daily, weekly, or monthly targets. A Gantt chart, which is widely used in project management, is one of the most popular and practical ways to represent activities (tasks or events) against time. A list of the activities may be found on the left side of the chart, and an appropriate time scale can be found along the top. Each action is represented by a bar, whose location and length indicate the activity's start, duration, and finish dates (https://www.gantt.com/).

On the challenge encountered in the process set by the Division Office in conducting research, the Division Office should review the Research Guidelines, as stipulated in DO No. 16 s 2017 or the Research Management Guidelines, and make them available to all teachers so that they are well-informed on how to undertake action research. There should be a clear outline on how to go about it and who is responsible for each phase.

The following are the other suggestions and proposed strategies by the researchers to help the teachers in doing action research and address the encountered challenges:

Information, Education, and Communication (IEC) is a method for spreading awareness to a target population through communication channels in order to accomplish a desired beneficial outcome (The Visual House, 2020). It is a method for disseminating information via broadcast or print media, as well as interpersonal contact, in a way that is appropriate for the target audience, in this case, teachers. IEC should be done, reproduced and disseminated to all teachers on a regular basis to inform them on how action research should be done and to help them eventually do or conduct their action research.

Mentoring programs are popular on-the-job trainings, according to reference (CliffNotes, 2020). A new employee or an employee is usually mentored by a seasoned veteran while they master their new position. This sort of instruction is sometimes referred to as an apprenticeship in the trades. In each case, the new employee is supervised by an experienced employee. As a result, this mentorship or coaching is incorporated in the action plan to pique teachers' interest in doing action research. They will be able to accomplish it if they are properly instructed. The teachers can seek help from those who have successfully conducted action research in their schools or within their district to make it easier to deal with the process of doing action research. Someone experienced will be a great help to a struggling beginner.

Finally, rewarding staff will increase their enthusiasm. The goal of recognition is to make workers feel valued and appreciated. Research has proven that employees who 
get recognized tend to have higher self-esteem, more confidence, more willingness to take on new challenges and more eagerness to be innovative.

\section{Conclusion}

Based on the findings of this study, the following may be claimed:

1. Action research, according to teachers, has a positive impact in the teaching-learning process. They believe that action research is very highly effective in the three aspects: teaching learning process, in their professional growth and development and in curriculum development.

2. For secondary teachers, doing action research is extremely difficult due to financial restrictions, time constraints, and the Division Office's procedure.

3. According to this survey, the teachers feel that using technology in writing and creating presentations is the least challenging aspect of doing action research.

4. A plan of action could be followed to help the teachers in doing action research and address the encountered challenges.

\section{Recommendation}

In view of the findings and conclusions of this study, the following are recommended: 1.Several measures can be done, those in the plan of action, to help the teachers in doing action research and address the encountered challenges.

2. Since this study discovered that action research is extremely beneficial in education, particularly in the teaching-learning process, teacher professional development, and curriculum creation, teachers should be encouraged to perform their own action research.

3. For the administration, they may take the advice and revise their rules for doing action research so that instructors don't have trouble following the procedure. While reducing teaching loads is not an option, as six (6) hours should be spent on teaching and two (2) hours on nonteaching tasks such as lesson planning and the like, administrators should look into other ways to assist instructors.

4. Future researchers might go more into the specific issues that teachers faced during the division process of doing action research, as this was not addressed in this study. They can also compare the conclusions of this study to those of other fields to see whether they are accurate. They might also look at why certain teachers in the division were unable to complete their action research.

\section{Conflict of Interest}

The researchers declare that the research was conducted in the absence of any commercial or financial relationships that could be construed as a potential conflict of interest.

\section{References}

1) Burns, Danny. (2014). Systemic action research: Changing system dynamics to support sustainable change. Action Research. 
2) Bhat, A. (2020). What is a descriptive research? URL https://www.questionpro.com/blog/descriptive-research/). Date Retrieved: February 13, 2020.

3) Calderon, Jose and Gonzales, Expectacion. (2006). Methods of research and thesis writing. Mandaluyong City: National Book Store

4) Chow, K.C.K. et.al. (2015). Teachers as Researchers: A discovery of Their Emerging Role and Impact Through a School-University Collaborative Research. Faculty of Education, The University of HongKong. URL: https://eric.ed.gov/?id=EJ1080020 Date Retrieved: July 4, 2020.

5) CliffNotes. (2020). Principles of Management: Orientation and Training Programs. URL: https://www.cliffsnotes.com/study-guides/principles-of-management/staffingand-human-resource- management/orientation-and-training-programs Date Retrieved: July 4, 2020.

6) Cochran-Smith, Marilyn \& Lytle, Susan. (1999). The teacher research movement: a decade later. Educational Researcher.

7) Creswell, John. (2003). Research Design: Qualitative, Quantitative, and Mixed-Method Approaches.

URL:https://www.researchgate.net/publication/225083951_Research_Design_Qualita tive_Quantitative_and_Mixed-Method_Approaches. Date Retrieved: February 11, 2020.

8) De Borja, J. (2018). Teacher Action Research: Its Difficulties and Implications. URL:

9) https://www.researchgate.net/publication/324980081. Date Retrieved: February 15, 2020.

10) Department of Education DepEd Order No. 16, series of 2017. URL: https://www.deped.gov.ph/2017/03/20/do-16-s-2017-research-managementguidelines/ Date Retrieved: February 16, 2020.

11) Dissertation Revision. (2017). Top 10 Challenges Faced by Researchers in Developing Countries. URL: https://www.dissertationrevision.com/ Date Retrieved: July 5, 2020

12) Ferrance, E. (2000). Themes in education: Action research. Brown University: Educational Alliance.

13) Great Schools Partnership. (2015). Action Research. The Glossary of Education. 82 Congress Street, Suite 500 Portland, ME. URL: https://www.edglossary.org/actionresearch/ Date Retrieved: June 3, 2020.

14) Hong, Carrie. \& Lawrence, Salika. (2011). Action Research in Teacher Education: Classroom Inquiry, Reflection, and Data-Driven Decision Making. William Patterson university.

15) Jamieson, Susan. (2007). Likert scale. Encyclopedia Britannica. URL:

16) https://www.britannica.com/topic/Likert-Scale Date Retrieved: February 11, 2020.

17) Johnson, Margaret \& Button, Kathryn. (2000). Connecting graduate education in language arts with teaching contexts: The power of action research. English Education.

18) Korthagen, Fred. \& Kessels, P.A.M. (1999) Linking theory and practice: changing the pedagogy of teacher education, Educational Research 
19) McLeod, Saul. 2019. What's the difference between qualitative and quantitative research?

20) Retrieved from: https://www.simplypsychology.org/qualitative-quantitative.html. Date Retrieved: July 4, 2020.

21) O'Connor, K. A., Greene, H. C., \& Anderson, P.J. (2006). Action research: A tool for improving teacher quality and classroom practice. Ontario Action Research. URL: https://www.researchgate.net/publication/234749663_Action_Research_A_Tool_for_ Improving_Teacher_Quality_and_Classroom_Practice. Date Retrieved: February 11, 2020.

22) Philippine Commission on Women. URL: https://www.pcw.gov.ph/ Date Retrieved: July 5, 2020

23) Pratheepkanth, P. (2011). Reward System and Its Impact on Employee Motivation in Commercial Bank of Sri Lanka Plc, In Jaffna District. Global Journals Inc. (USA).

24) Ross, John, Rolheiser, Carol, \& Hogoboam-Gray, Anne. (1999). Effects of collaborative action research on the

25) Sagor, Richard. (2004). The action research guidebook: A four-step process for educators and school teams. Thousand Oaks, CA: Sage knowledge of five Canadian teacher researchers. The Elementary School Journal.

26) Sax, Caren \& Fisher, Douglas. (2001) Using qualitative action research to effect change: Implications for professional education. Teacher Education Quarterly. URL: https://www.jstor.org/stable/23478278?seq=1 Date Retrieved: February 12, 2020.

27) Schnitzer, K. \& Fabiano, J. (2019). Generation X: Five main generation $X$ characteristics you see in the workplace. URL: https://www.theladders.com/careeradvice/these-are-generation- $x$-characteristics-in-the-office-and-their-new-label. Date Retrieved: July 4, 2020.

28) Teach for the Philippines Organization (2013). President Aquino Signs K+12 Program into Law. May 29, 2013. URL: https://teachforthephilippines.org/our_press/presidentaquino-signs-k12-into-law/ Date Retrieved: February 11, 2020.

29) The Visual House. (2020). Role of Information Education \& Communication (IEC) in Rural Development.URL: https://www.thevisualhouse.in/blog/role-of-informationeducation-communication Date Retrieved: July 4, 2020.

30) Tindowen, Guzman and Macanang (2019). Teachers' Conception and Difficulties in Doing Action Research. University of Saint Louis, Tuguegarao City, Philippines. URL: https://www.researchgate.net/publication/334963031 Date Retrieved: February 12, 2020.

31) Torreces, R. (2019). Action Research Guide. Division of Iloilo. URL:

32) https://www.slideshare.net/Ramskyprince/action-research-2019pdf. Date Retrieved: July 4, 2020.

33) What is a Gantt chart? Retrieved from: https://www.gantt.com/. Date Retrieved: July 4, 2020.

34) Zhang, M., Lundeberg, M., McConnell, T. J., Koehler, M. J., \& Eberhardt, J. (2010). Using questioning to facilitate discussion of science teaching problems in teacher professional development. The Interdisciplinary Journal of Problem-based Learning. 